\title{
Desempenho sócio-cognitivo e adaptação sócio-comunicativa em diferentes grupos inclúdos no espectro autístico****
}

\author{
Social-cognitive performance and social-communicative adaptation \\ in different groups of the autistic spectrum
}

\author{
Carla Cardoso* \\ Priscilla Faria Sousa-Morato** \\ Suraia Andrade*** \\ Fernanda Dreux Miranda Fernandes****
}

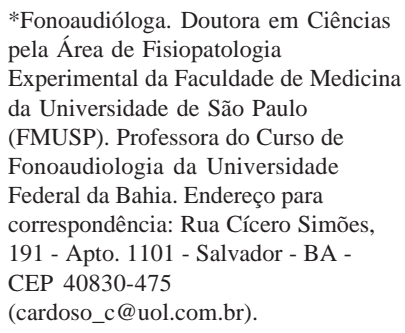

*Fonoaudióloga. Doutora em Ciências pela Área de Fisiopatologia Experimental da Faculdade de Medicina da Universidade de São Paulo (FMUSP). Professora do Curso de Fonoaudiologia da Universidade Federal da Bahia. Endereço para correspondência: Rua Cícero Simões, 191 - Apto. 1101 - Salvador - BA CEP 40830-475

(cardoso_c@uol.com.br).

**Fonoaudióloga. Doutora em Linguística pelo Departamento de Linguística da Faculdade de Filosofia, Letras e Ciências Humanas da USP. Professora do Curso de Fonoaudiologia da Fundação Mineira de Educação e Cultura - Belo Horizonte - MG.

***Fonoaudióloga Clínica. Supervisora Assistente do

Ambulatório de Atendimento Fonoaudiológico nos Distúrbios do Desenvolvimento na Clinica Escola Evolução (Salvador - BA).

****Fonoaudióloga. Doutora em Semiótica e Linguistica Geral. Docente do Curso de Fonoaudiologia da FMUSP.

*****Trabalho Realizado no Laboratório de Investigação Fonoaudiológica em Distúrbios Psiquiátricos da Infância do Curso de Fonoaudiologia da FMUSP e no Ambulatório de Atendimento Fonoaudiológico nos Distúrbios do Desenvolvimento na Clinica Escola Evolução (Salvador - BA).

Artigo Original de Pesquisa

Artigo Submetido a Avaliação por Pares

Conflito de Interesse: não

Recebido em 02.03.2009.

Revisado em 02.10.2009; 23.11.2009; 02.12.2009.

Aceito para Publicação em 01.02.2010.

\section{Abstract}

Background: researches about the relationship between language, cognition and socialization have evolved since the 70s. Language mediates social development allowing the individual to participate in social situations that include balanced communicative exchanges. Aim: to assess the effectiveness of the Social-Communicative Adaptation Protocol in two groups of children and adolescents with autistic spectrum disorders and to verify the relationship between the referred protocol and the Social-Cognitive Profile. Method: participants were 16 children and adolescents with ages between 8.0 and 16.0 years, of both genders, who were diagnosed within the autistic spectrum by neurologists and/or psychiatrists. All participants were receiving, once a week, specialized language therapy by a speech-language pathologist for a period of at least six months. Participants were assessed using the Social-cognitive Profile and the Social-Communicative Adaptation questionnaire. Results: the analysis of the results indicated absence of significant statistical differences in the Social-Cognitive Profile between the two groups. The Social-Communicative Adaptation demonstrated to be extremely variable among the participants. Conclusion: this research shows that autistic spectrum children do not have a symmetric and linear development of language, socialization and cognition.

Key Words: Autistic Disorder; Child Language; Cognition.

\section{Resumo}

Tema: as pesquisas quanto à inter-relação entre os aspectos de linguagem, cognição e socialização, vêm evoluindo desde a década de 70. Na perspectiva pragmática a linguagem é mediadora do desenvolvimento da socialização, permitindo ao indivíduo participar das relações sociais que expressam trocas comunicativas simétricas. Objetivo: verificar a efetividade da aplicação do protocolo de adaptação sócio-comunicativa em dois grupos de crianças e adolescentes com diagnósticos inseridos no espectro autístico, em atendimento fonoaudiológico especializado, em diferentes instituições, e verificar a relação entre os dados coletados no protocolo de adaptação sócio-comunicativa e o desempenho sócio-cognitivo. Método: participaram desta pesquisa 16 crianças e adolescentes na faixa etária de 8,0 a 16,0 anos, de ambos os gêneros, diagnosticados por médicos neurologistas e/ou psiquiatras como portadores de distúrbios incluídos no espectro autístico segundo os critérios específicos ${ }^{1-2}$. Todas as crianças estavam em atendimento fonoaudiológico semanal especializado por um período mínimo de seis meses. Foram aplicados os protocolos de analise dos Aspectos Sócio-Cognitivos ${ }^{3}$ e para a coleta de dados da Adaptação Sócio-comunicativa foram utilizados o protocolo e o questionário específico propostos por Sousa ${ }^{4}$. Resultados: na análise dos resultados obtidos foi possível verificar que não houve diferenças estatisticamente significativas quanto ao desempenho sócio-cognitivo dos dois grupos, sendo a adaptação sócio-comunicativa dessas crianças extremamente variável. Conclusão: sendo assim, fica claro que, com o grupo de crianças do espectro autistico participantes deste estudo, é possível verificar que o desenvolvimento lingüístico, social e cognitivo não acontece de forma simétrica e linear.

Palavras-Chave: Transtorno Autistico; Linguagem; Cognição.

Referenciar este material como:

Cardoso C, Sousa-Morato PF, Andrade S, Fernandes FDM. Social-cognitive performance and social-communicative adaptation in different groups of the autistic 53 spectrum (original title: Desempenho sócio-cognitivo e adaptação sócio-comunicativa em diferentes grupos incluídos no espectro autístico). Pró-Fono Revista de Atualização Científica. 2010 jan-mar;22(1):43-8. 


\section{Introduction}

The identification of Infantile Autism involves three symptomatic axles: interpersonal relations, communication and behavior, considering that the disorder must have its onset before the 36th month of life. The great variability in the interaction between those domains justify the use of the term Autism Spectrum to describe the clinical features (5).

Some studies have shown that social attention deficits in face to face social interaction, communication, emotion, performance of interactive actions, impairments in understanding and using social smile and facial expressions are fundamental differences between autistic and typical developing children $(6,7,8,9,10)$. These impairments in the abilities necessary to participate in social interaction pose difficulties to the interaction of autistic children with other children and may also delay or enlarge the gap in social behavior development between these children and their normal peers $(11,5)$.

This way, the purpose of the present study was to verify the effectiveness of the application of the social-communicative adaptation protocol in two groups of children and adolescents of the autistic spectrum attending specialized language therapy in two different institutions and compare them with data about the social-cognitive performance.

\section{Method}

Data gathering started after the research was approved by the ethic committees (FJA 001/2001 and Cappesq 382/04).

\section{Subjects}

Participated in the study 16 children and adolescents between 8:0 and 16:00 years, of both genders, with diagnosis determined by neurologists and/or psychiatrists, as having autism spectrum disorders, according to the specific criteria proposed by IDC-10 (1) and DSM-IV (2). All subjects should be attending weekly specialized language therapy for at least six months and were divided in two groups:

. Group 1: comprised by 8 subjects, mean age 12:38y (standard deviation 3:02y), living in Salvador (BA) and attending weekly language therapy in a clinicalschool.

. Group 2: comprised by 8 subjects, mean age 11:38y (standard deviation 3:29y), living in the Great São Paulo area (SP), attending weekly language therapy in a specialized university service.
Material

\section{Social cognitive performance}

The following objects were used: toy or object of interest to the child, piece of cloth, "bionic hand", pointless pencil, sharpener, trash basket, adhesive tape, paper, miniature house with furniture, toy car and telephone.

\section{Social-communicative adaptation}

The specific questionnaire and protocol were used (4).

Procedures

Social cognitive performance

The test proposed by Molini-Avejonas and Fernandes (3) was used, assessing the following aspects: gestual communicative intent, vocal communicative intent, tool use, gestual imitation, vocal imitation, combinatory play and symbolic play. The results were registered in specific protocols (appendix 2).

\section{Social-communicative adaptation}

The social-communicative adaptation protocols were used individually during interviews conducted by one of the researchers with the parents of the subjects. They should answer yes or no to questions about the social adaptation performance of their children. To each positive answer was attributed a score 1 and each negative answer received score 0 to allow the statistical analysis of data.

Result analisis

The Statistical Package for Social Sciences, version 13.0 with significance level of $5 \%(=0,050)$ was used. When the significance result (p) was lower than $5 \%(0.050)$, it was considered a significant difference and when it was higher than 5\% (0.050) there is a non-significant difference, i.e. a similarity.

The Mann-Whitney test was used to verify the possible differences between groups while the Spearman Correlation Analysis had the objective to verify the relationshio level among variables (12). 


\section{Resultados}

The analysis of the results verified that there was no statistically significant differences regarding the social-cognitive performance of both groups, as presented in Table 1.

The answers about the social-communicative adaptation obtained through different

information sources, i.e, parents of autistic children were generically similar according to the statistical analysis. However, the socialcommunicative adaptation of these children is extremely varied and it is increasingly differentiated from the moment the child needs to identify, understand and accept the intervention of others as participating agents of collaboration and cocreation.

According to the Mann-Whitney test, statistical analysis of the results it can be stated that there is a tendency of similarity among the answers provided by the parents of the children of both groups of this study in what refer to the socialcommunicative adaptation. It can be observed that the results were homogeneous.

Table 2 presents the correlation that determined statistically significant differences to Groups 1 and 2 and their respective comments.

TABLE 1. Comparison of the areas of social-cognitive performance of different groups of children of the autistic spectrum.

\begin{tabular}{|c|c|c|c|c|}
\hline Variable & group & Mean & Standard deviation & Significance (p) \\
\hline \multirow{3}{*}{ Gestual Communicative Intent } & 1 & 4.63 & $1 ., 30$ & \multirow{3}{*}{$0 . .541$} \\
\hline & & & & \\
\hline & 2 & 4.25 & 1.49 & \\
\hline \multirow{3}{*}{ Verbal Communicative Intent } & 1 & 4.75 & 1.28 & \multirow{3}{*}{0.297} \\
\hline & & & & \\
\hline & 2 & 3.88 & 1.81 & \\
\hline \multirow{3}{*}{ Tool use } & 1 & 1.38 & 1.41 & \multirow{3}{*}{0.318} \\
\hline & & & & \\
\hline & 2 & 0.60 & 0.55 & \\
\hline \multirow{3}{*}{ Ggestual imitation } & 1 & 1.63 & 1.06 & \multirow{3}{*}{0.127} \\
\hline & & & & \\
\hline & 2 & 1.13 & 0.35 & \\
\hline \multirow{3}{*}{ Vocal imitation } & 1 & 1.25 & 1.04 & \multirow{3}{*}{0.535} \\
\hline & & & & \\
\hline & 2 & 1.50 & 0.55 & \\
\hline \multirow{3}{*}{ Combinatory play } & 1 & 3.63 & 1.51 & \multirow{3}{*}{0.914} \\
\hline & & & & \\
\hline & 2 & 3.75 & 1.83 & \\
\hline \multirow{3}{*}{ Symbolic Play } & 1 & 3.50 & 1.20 & \multirow{3}{*}{0.870} \\
\hline & & & & \\
\hline & 2 & 3.38 & 1.41 & \\
\hline
\end{tabular}


FIGURE 1. Comparison of the positive answers regarding the social-communicative scale of different groups of children of the autism spectrum

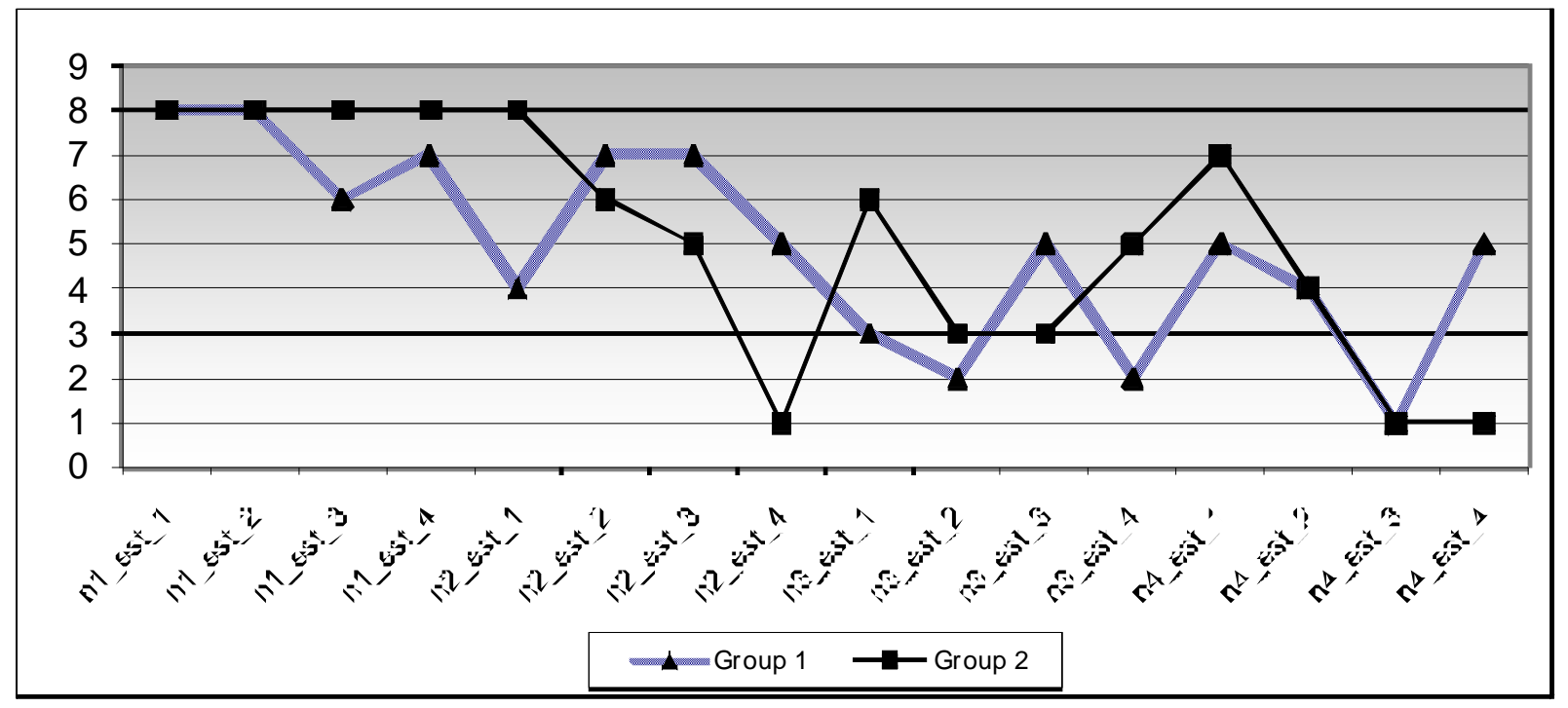

TABLE 2. Significant correlations among the social-cognitive performance and social communicative adaptation in Groups 1 and 2 .

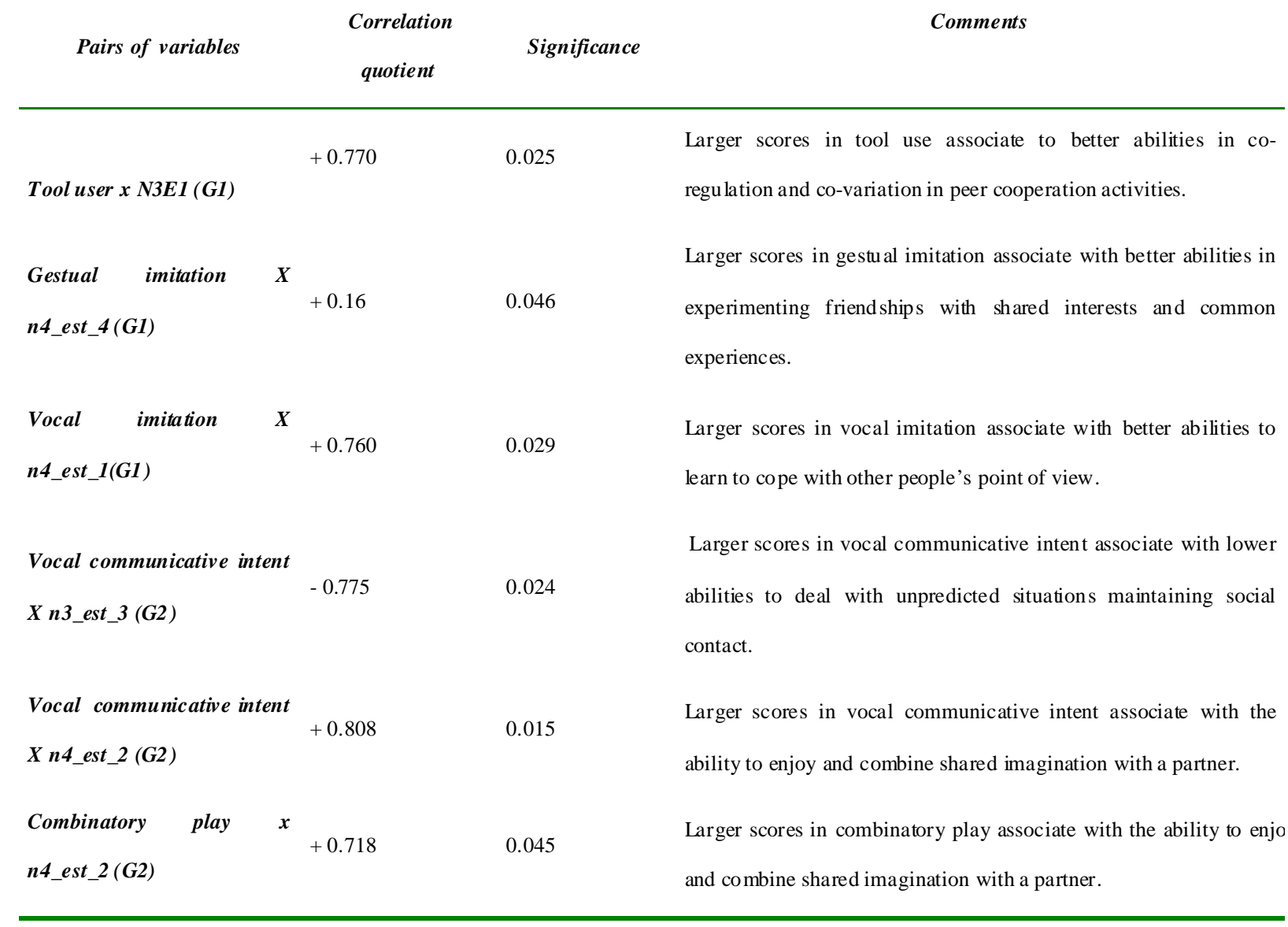




\section{Discussion}

The objectivity in the assessment of the social development of children of the autism spectrum is important because the identification of the social relations level is useful to the qualitative and quantitative identification and discrimination of the obtained progress, as suggested by studies conducted by Gutstein (13).

The application of the social-communicative adaptation questionnaire and protocol with different informants may lead to homogeneous results, allowing the characterization of the social relation abilities of these children. These data agree with several studies $(14,15,16,17,18)$ in the sense that the inclusion of the perspective of the parents of children of the autism spectrum in what refer to the linguistic, cognitive and social behavior of their children deserves attention. It allows a partnership with the professionals involved in the intervention process contributing to the assessment of the developmental level of these children.

Despite the analysis of this study didn't identify many significant variables among the assessed areas, it was possible to observe variations referring to vocal and gestual imitation and to vocal and gestual communicative intent, what can be related to the therapeutic aim that is to improve social interaction and also to the great individual differences, as suggested by previous studies $(3.19,20)$.

Some authors state that it is possible to gather useful information about the progress of children of the autism spectrum when the parents are the informants $(14,15,16,21)$. These same studies have shown that data obtained through questionnaires applied to parents are useful to the individual assessment process and therapeutic planning with a low cost.

It can be observed that the social-communicative behavior of children of the autism spectrum is extremely varied and it is increasingly differentiated from the moment the child needs to identify, understand and accept the intervention of others as participating agents of collaboration and co-creation, a development that has different characteristic and rhythms, due to the individual variations. This behavior can be noted from the stage 3 of level 2 of the social-communicative adaptation scale, in which the child must use reference and regulation abilities in order to function as a partner of coordinated actions.

Another interesting data observed is the large number of positive answers to 1 and 2 stages of level 1 of the social-communicative adaptation scale where it is asked if their children share experiences and emotions with actions during face to face interactions and if they understand and use the partner's non-verbal expressions as a critical point of reference to their actions, what do not entirely agree with prior studies by Adrien et al 6, Adrien et al 7, Baron-Cohen et al 8, Downs e Smith 9 e Leekam e Ramsden 10. These authors suggest that the ability to understand other people's actions and emotions in not developed in autistic children and is a fundamental aspect to their social impairment.

The communicative context in which these children develop should not be overlooked, as mentioned by Yont et al (22). These factors may be responsible for a great part of the great individual variations observed in the same levels of socialcommunicative adaptation.

Comparing the two groups that participated in this study it can be noted that the differences among them are not enough to identify determinant characteristics of social-communicative adaptation development neither of social-cognitive development. However, it can be observed that there are individual variations, i.e, children with the same psychiatric diagnosis do not present the same characteristics and therefore these characteristics cannot be used as elements to the differential diagnosis.

The presence of positive and negative correlations associated to the Gestual Communicative Intent and to the social-communicative adaptation levels and stages may be related to the use of alternative means of communication, as the gestures, to convey a variety of communicative functions. Positive correlations among vocal and gestual imitation abilities and socialcommunicative adaptation development agree with the studies by Ingersoll \& Schreibman 23. These authors observed that children of the autism spectrum developed their imitation abilities, were capable of generalizing them to new situations and presented social-communicative behavioral gains that included language, symbolic play and joint attention. It is also necessary to mention that these data disagree with previous findings by Hwang \& Hughes 11 and Clifford et al 5 in the sense that children with autism frequently present important deficits in social exchange, as joint attention and social imitative play. The present study suggests that there is not a systematic causal relation between the different studied abilities.

These studies' findings may be compared with prior studies, allowing the identification of individual differences among children of the autism spectrum in what refer to the social-communicative adaptation $(4,18,21)$. It is also possible to observe that the social cognitive aspects function independently in relation to the social-communicative aspects, but the existence of a positive correlation between them cannot be denied, what doesn't imply causality. 


\section{Conclusion}

The use of specific tests and tasks - despite involving the need of collaboration and understanding by the subjects, parents and caregivers and not being the only source of data about the subject - allow the assessment of important objective data that may contribute to the speech and language diagnostic. The more precise and detailed the diagnostic understanding, the better will be the adaptation of the therapeutic intervention process to each subject's individual need. Besides, these data will allow the follow-up of any intervention process, favoring the information exchange between professionals and parents.

From the exposed in this study, it was possible to verify that the social-communicative adaptation protocol be one more assessment instrument to obtain information from parents.

\section{References}

1. Organização mundial de saúde. Classificação de transtornos mentais de comportamento - CID-10- Critérios diagnósticos para pesquisa. Porto Alegre: Artes Médicas; 1983.

2. American Psychiatry Association - DSM-IV. Manual diagnóstico estatístico de transtornos mentais. Porto Alegre: Artes Médicas; 1994.

3. Molini-Avejonas DR, Fernandes FDM. Intenção comunicativa e uso de instrumento em crianças com distúrbios psiquiátricos. Pró-Fono. 2003;15:149-58.

4. Sousa PFG. Relações entre o perfil comunicativo, desempenho sócio-cognitivo e adaptação sóciocomunicativa em crianças com transtornos do espectro autístico. [dissertação]. São Paulo: Faculdade de Filosofia, Letras e Ciências Humanas - Universidade de São Paulo; 2004.

5. Clifford S, Young R, Willianson P. Assessing the early characteristics of autistic disorder using video analysis. J Autism Dev Disord. 2007.

6. Adrien JL, Perrot A, Hameury L, Martineau J, Roux S, Sauvage D. Family home movies: identification of early autistic signs in infants later diagnosed as autistics. Brain Dysf. 1991;4:355-62.

7. Adrien JL, Lenoir P, Martineau J, Perrot A, Hameury L, Larmande C, Sauvage D. Blind ratings of early symptoms of autism based upon family home movies. J Amer Acad Child Adoles Psychi. 1993;32:617-26.

8. Baron-Cohen S, Cox A, Baird G, Swetteham J; Nightingale N, Morgan K, Drew A, Charmant T. Psychological markers in the detection of autism in infancy in a large population. Brit J Psychi. 1996;168(2):158-63.

9. Downs A, Smith T. Emotional understanding, cooperation, and social behavior in high-functioning children with autism? J Autism Dev Disord. 2004;34(6).

10. Leekam SR, Ramsden CAH. Dyadic orienting and joint attention in preschool children with autism. J Autism Dev Disord. 2006;36(2):185-97.

11. Hwang B, Hughes C. The effects of social interactive training on early social communicative skills of children with autism. J Autism Dev Disord. 2000;30(4):331-43.

12. Maxwell DL, Satake E. Research and statistical methods in communication disorders. Baltminore: Willians e Wilkins; 1997.
13. Gutstein S. Solving the relationship puzzle. Arlington, Texas: Future Horizons; 2000.

14. Charman T, Howlin P, Berry B, Prince E. Measuring developmental progress of children with autism spectrum disorder on school entry using parent report. Autism. 2004; 8(1):89-100.

15. Siperstein R, Volkmalk F. Brief report: parental reporting of regression in children with pervasive developmental disorders. J Autism Dev Disord. 2004;34(6):731-4.

16. Eaves LC, Wingert HD; Howk HH; Mickelson ECR. Screening for autism spectrum disorders with the social communication questionnaire. J Dev Behav Pediatr. 2006; 27(2):95-103.

17. Moes DR, Frea WD. Contextualized behavioral support in early intervention for children with autism and their families. J Autism Dev Disord. 2002;32(6):519-33.

18. Sousa-Morato PF, Fernandes FDM. Relações entre o desempenho sócio-cognitivo e a adaptação sóciocomunicativa em crianças do espectro autístico. Rev Soc Bras Fonoaudiol. 2006b;11(4):243-9.

19. Fernandes FDM. Atuação fonoaudiológica com crianças com transtornos do espectro autístico [tese]. São Paulo: Faculdade de Medicina, Universidade de São Paulo; 2002.

20. Fernandes FDM. Sugestões de procedimentos terapêuticos de linguagem em distúrbios de espectro autístico. In: Limongi SCO, organizadora. Fonoaudiologia - informação para a formação. Rio de Janeiro: Guanabara Koogan; 2003. p. 55-65

21.Sousa-Morato PF; Fernandes FDM. Análise do perfil sócio-comunicativo quanto à adaptação sócio-comunicativa em crianças do espectro autístico. Rev Soc Bras de Fonoaudiol. 2006a;11(2);70-4.

22. Yont KM, Snow CE, Vernon-Fegans L. The role of context in mother-child interactions: an analysis of communicative intents expressed during toy play and book reading with 12-month-olds. Journal of Pragmatics. 2003; 35:435-54.

23. Ingersoll B, Schreibman L. Teaching reciprocal imitation skills to young children with autism using a naturalistic behavioral approach: effects on language, pretend play, and joint attention. J Autism Dev Disord. 2006;36(4):487505 . 